\title{
A taxonomic revision of genus Phloeophila (Orchidaceae, Pleurothallidinae) in Ecuador
}

\author{
Marco M. Jiménez ${ }^{1,2,3^{*}}$, Leisberth Vélez-Abarca ${ }^{3,4}$, Luis E. Baquero ${ }^{3,5}$ \& Carlos Naranjo ${ }^{6}$
}

\section{Article info}

Received: 21 Sept. 2020

Revision received: 23 Nov. 2020

Accepted: 25 Nov. 2020

Published: 9 Jun. 2021

\section{Associate Editor}

Marcial Escudero

\begin{abstract}
The orchid genus Phloeophila is distributed from southern Mexico to Brazil and Bolivia, as well as Cuba. A taxonomic revision including the three Phloeophila species present in Ecuador is presented. Morphological characteristics, an identification key, maps of known localities and illustrations of the species are also included. In Ecuador, species of Phloeophila are only known from the Amazonian rainforests, growing from 890 to 1600 meters of altitude. Phloeophila condorana is described as a new species based on specimens collected in the Ecuadorian province of Zamora-Chinchipe and compared to Phloeophila nummularia. Phloeophila nummularia is reported for the first time in Peru. A lectotype for Pleurothallis echinantha is selected.
\end{abstract}

Key words: Amazon, new species, orchid, rainforests, taxonomy

\section{Introduction}

The subtribe Pleurothallidinae with more than 5000 species is considered the most diverse in species of all orchids and is currently divided in nine major clades (Karremans 2016). Phloeophila is a small genus of the Pleurothallidinae with three species distributed throughout Tropical America from Mexico, Central America, the Antilles, to Bolivia and Brazil (Karremans \& Vieira-Uribe 2020).

The first Phloeophila collections were made in the late 19th century by Charles Wright (1859, Cuba) (Fig. 1), Joao Barbosa Rodrigues (Brazil) and Friedrich Lehmann (Colombia). In 1865, Reichenbach described the first species attributable to Phloeophila as Pleurothallis nuтmиlaria based on material collected by Wright. In 1926, Hoehne and Schlechter established the genus with two species: P. echinantha and P. paulensis, designating the latter as the type species (Luer 2006).

\footnotetext{
${ }^{1}$ Maestría en Biología de la Conservación y Ecología Tropical, Universidad Técnica Particular de Loja, Loja, Ecuador

2 Vivero de Conservación La Paphinia, Avenida del Ejército y Juan Izquierdo, Zamora 190102, Ecuador

${ }^{3}$ Grupo Científico Calaway Dodson: Investigación y Conservación de Orquídeas del Ecuador, Quito, Ecuador

${ }^{4}$ Carrera de Biología, Universidad Estatal Amazónica (Sede El Pangui), Luis Imaicela entre Azuay y Mayor Rene Ulloa, El Pangui, Zamora Chinchipe, Ecuador

${ }^{5}$ Grupo de Investigación en Medio Ambiente y Salud BIOMAS, Carrera de Ingeniería Agroindustrial y Alimentos. Facultad de Ingeniería y Ciencias Agropecuarias. Universidad de Las Américas, Calle José Queri, Quito 170137, Pichincha, Ecuador

6 Sección de Ecología y Sistemática, Departamento de Ciencias Biológicas, Universidad Técnica Particular de Loja, San Cayetano s/n, Loja 1101608, Ecuador

*Corresponding author e-mail: mmjimenez@utpl.edu.ec
}

Subsequently, Garay (1974) included new taxa from different Pleurothallidinae lineages in the genus (López, Solano \& Pérez-Farrera 2007). Later, in his taxonomic study of Pleurothallis Luer (1986) considered Phloeophila as a section of subgenus Acianthera (Chiron et al. 2016; López et al. 2007). In 2006, Luer changed his opinion bringing back Phloeophila as a genus encompassing four species (Luer 2006).

Pridgeon et al. (2001), on the basis of DNA analysis, found that the species of Phloeophila form a monophyletic clade together with the species previously placed in Luerella and Ophidion. They subsequently combined these three groups into a broader circumscription of Phloeophila (Pridgeon \& Chase 2001). Chiron et al. (2016) maintained this circumscription of Phloeophila from Pridgeon \& Chase (2001). Recently, Karremans \& Vieira-Uribe (2020) on the basis of molecular analysis of Chumová, Ponert and co-workers (Chumóva et al. 2018; Ponert et al. 2019) and considering the lack of diagnostic features in the broad Phloeophila, reestablished the genera mentioned before to their original concept, transferred $P$. oricola from Cuba to Acianthera and considered the Mesoamerican P. peperomioides as a synonym of the Brazilian P. echinantha.

Species of Phloeophila are epiphytes recognized by their small, prostrate plants with markedly abbreviated ramicauls, the leaves are prostrate, thickly coriaceous, verrucose, suborbicular, the flowers are small, spiculate externally, fleshy, proportionally as large or larger than the leaves, produced singly, the lateral sepals are connate to form a broad synsepal (Fig. 2), the petals are acute to subacute, erose at the apex and the lip is oblong with 


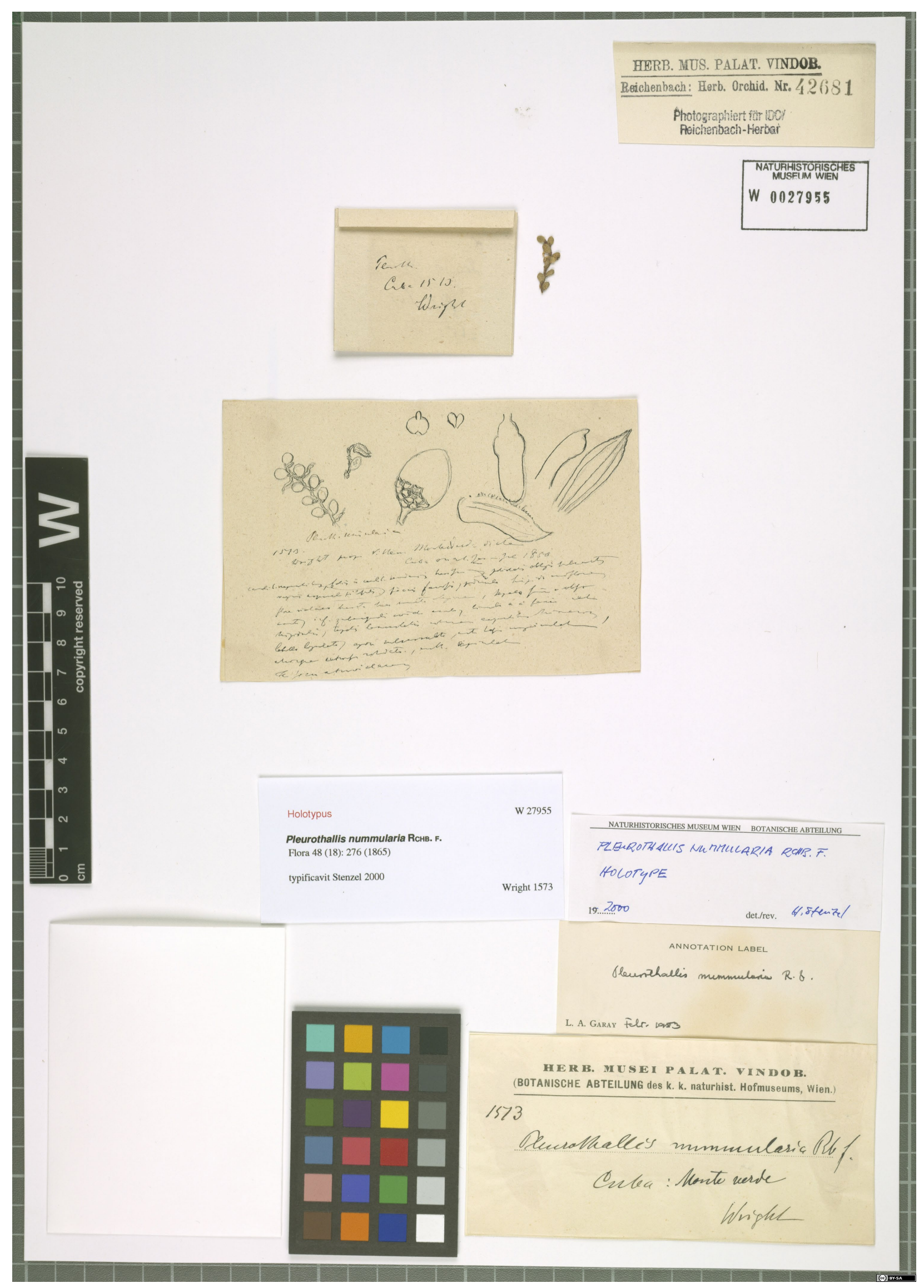

Figure 1. Holotype of Pleurothallis nummularia. [Herbarium W, W0027955]. Reproduced with the kind permission the Natural History Museum, Vienna - Herbarium W. Occurrence dataset https://doi.org/10.15468/5s17sh accessed via GBIF.org on 2020-09-20. https://www.gbif.org/ occurrence/1231006737 
erect margins below the middle, articulated to the column (Luer 2006; Karremans \& Vieira-Uribe 2020).

Hitherto, a total of two species have been registered in Ecuador: Phloeophila nummularia, and P. ursula (Luer 2006, 2004). A color photograph of the holotype of $P$. ursula was included in the book Native Ecuadorian Orchids IV (Dodson 2003). During exploration aimed to determine part of the orchid diversity of the Cordillera del Cóndor in southeastern Ecuador, a new species of Phloeophila was discovered and is described here.

Considering that Phloeophila is a poorly morphologically known genus with cryptic species, without any previous taxonomic revisions in Ecuador, the present study aims:

(1) To determine and circumscribe the genus in Ecuador by means of a taxonomic treatment.

(2) To synthesize the taxonomy and the circumscription of the Ecuadorian species of the genus based on data of the geographical distribution, the study of living and herbarium material of plants in flower and description of new taxa.

\section{Materials and methods}

Plants of the species examined in this study were collected under permit No021-2019-IC-FLO-FAU-DPAZCHUPN-VS / MA granted by the Ministerio del Ambiente of Ecuador. The material collected in the field was illustrated, preserved as exsiccata and stored in $70 \%$ ethanol and glycerine. Living specimens are cultivated by the Vivero de Conservación La Paphinia in Zamora and were photographed using a Panasonic ${ }^{\circledR}$ FZ300 camera and a Raynox DCR-150 $50 \mathrm{~mm}$ lens. Measurements were based on photos with a $30 \mathrm{~cm}$ ruler and using the ImageJ processing program (National Institutes of Health) downloaded from https://imagej.nih.gov/ (Lind 2012). Original descriptions from holotypes of related species (Luer 1996, 2006) were consulted and compared. The ArcMap program in ArcGIS (ESRI) was employed to produce the distribution maps of described species of Phloeophila in Ecuador and the new species (Fig. 4). Species collection localities were obtained from Luer (2006).

Furthermore, based on the morphological characters of living specimens, a taxonomic key and descriptions were provided. Photographs and specimens from herbaria BR, GH, HUT, K and NY were studied.

\section{Taxonomy}

Phloeophila Hoehne \& Schltr. Archivos de Botânica do São Paulo 1(3): 199. 1926.

Lectotype: Phloeophila paulensis Hoehne \& Schltr. Archivos de Botânica do São Paulo 1: 2001. 1926.

= Phloeophila nummularia (Rchb. f.) Garay, Orquideología 9(2): 118. 1974.

Generic synonym: Pleurothallis sect. Phloeophilae Luer, Monogr. Syst. Bot. Missouri Bot. Gard. 20: 17. 1986.

Description. Plants epiphytic, caespitose, prostrate. Rhizome elongate. Roots flexuous, slender, cylindrical, less than $1 \mathrm{~mm}$ in diameter. Ramicauls terete, proportionately stout, unifoliate, ascending, markedly abbreviated, subtended by 1-2 tubular, imbricate, persistent, scarious, sheaths. Leaves prone, thickly coriaceous, verrucose, suborbicular, obtuse, narrowed below into a subsessile base. Inflorescence erect, single-flowered, peduncle slender, terete, to $8 \mathrm{~mm}$ long, puberulent or spiculate, produced from the base of the ramicaul, spathe lacking; floral bracts spiculate, pedicels slender or obconical, ovary spiculate. Flowers minute, resupinate. Sepals variously colored, fleshy, puberulent or spiculate externally, sometimes minutely pubescent within, dorsal connate to the base of the synsepal, lateral sepals broad, connate at least to the middle into a concave synsepal. Petals fleshy, simple, free, acute. Lip oblong-subtrilobed, simple with obscure or obvious angles of lobes below the middle, the base more or less truncate hinged to the column-foot. Column slender, semiterete, shallowly concave ventrally, denticulate at the apex, the anther and stigma ventral, the pollinia two, obovoid, pyriform.

\section{Key to the Ecuadorian species of Phloeophila}

1(a) Perianth up to $7 \mathrm{~mm}$ long, striped, variously spiculate externally, synsepal, connate to near the apex .... 2

1(b) Perianth up to $10 \mathrm{~mm}$ long, spotted, densely pubescent externally, synsepal connate near the middle ....... $\ldots \ldots \ldots \ldots \ldots \ldots \ldots$. . . . . . . . . . . . . . .

2(a) Peduncle $1 \mathrm{~mm}$ long, sepals yellow and red colored, synsepal slightly concave below the middle, petals triangular-ovate with yellow veins, lip verrucose-glandular adaxially . . . . . . . . . . condorana

2(b) Peduncle $8 \mathrm{~mm}$ long, sepals whitish gray and yellow-brown colored, synsepal concave as a broad tube, petals oblong with brown veins, lip verrucose-pubescent adaxially . . . . . . . . . . . . nummularia

\section{Species descriptions}

Phloeophila condorana M.M. Jiménez \& Vélez-Abarca sp. nov.

(Figs 2-5)

Diagnosis: This species is similar to $P$. nummularia from which it differs by its $1 \mathrm{~mm}$ long peduncle (vs $8 \mathrm{~mm}$ ), the sepals yellow and red colored with cinnamon brown stripes (vs whitish gray and yellow sepals with reddish purple stripes), slightly spiculate on the outside (vs sparsely pubescent), the synsepal slightly concave below the middle (vs connate into a broad tube), the inner integument glandular (vs finely pubescent), the petals triangular-ovate with yellow veins (vs oblong with brown stripes), the lip verrucose-glandular adaxially (vs pubescent-verrucose adaxially) and the column yellow, lobed and dentate at the apex (vs yellowish brown with stripes, erose and cucullate at the apex).

Type: Ecuador. Zamora Chinchipe: Cordillera del Cóndor flank, near El Pangui, 343'05"S, 78³3'16"W, 893 m, 4 June 2020, M.M. Jiménez \& L. Vélez-Abarca 991 (HUTPL - holotype!; plant in alcohol). In the same area, $980 \mathrm{~m}, 17$ August 2020, L. Vélez-Abarca 42 (ECUAMZ - paratype!).

Plant epiphytic, repent, up to $7.5 \mathrm{~cm}$ long. Roots thick, flexuous, whitish brown, $0.3-0.7 \mathrm{~mm}$ diameter, produced every one or two internodes of the rhizome. Rhizome 


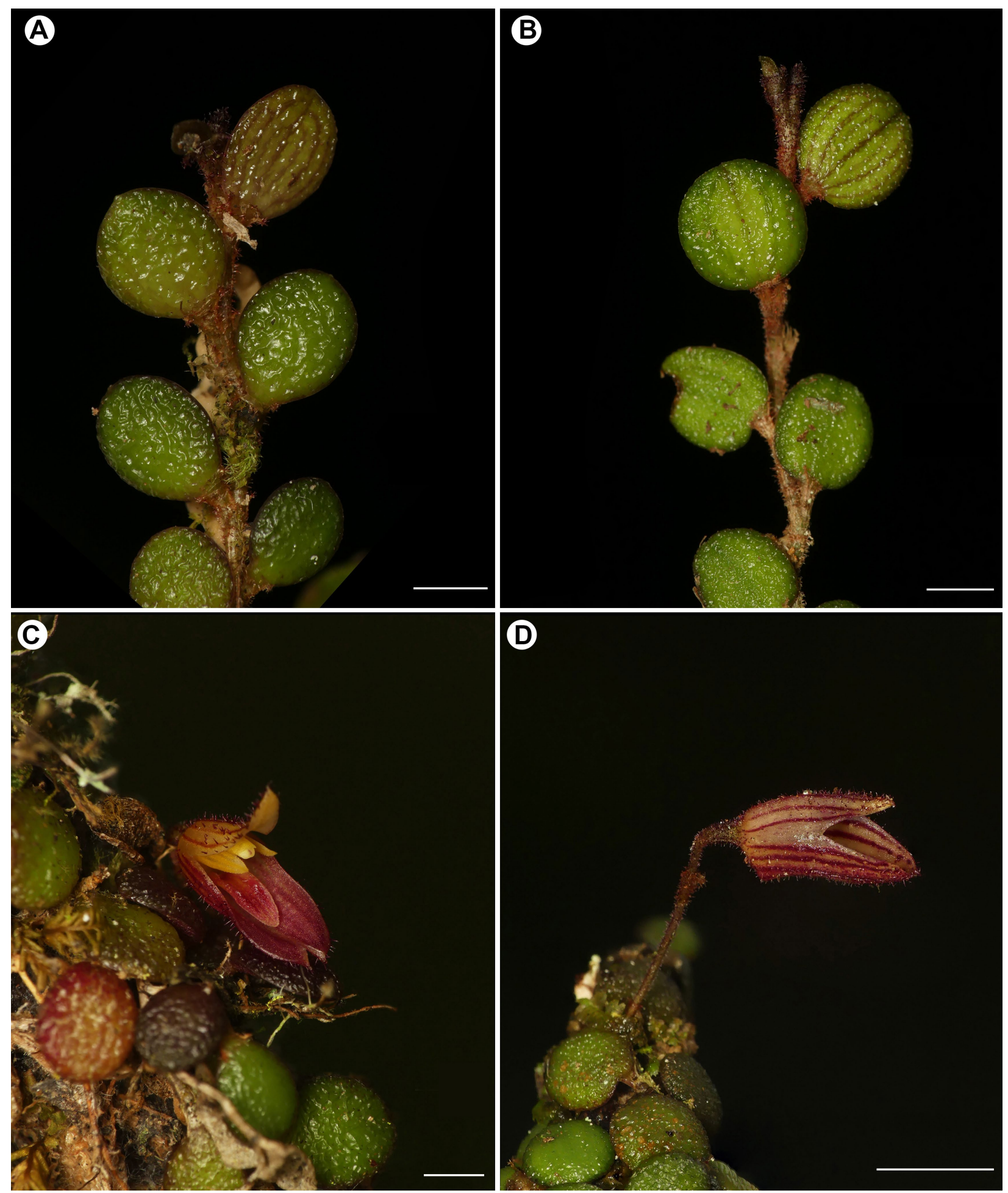

Figure 2. Leaves and flowers of Phloeophila species from Ecuador. [A, C: Jiménez 991; B, D: Jiménez 998]. A-C - P. condorana; B-D - P. nummularia. Scales: A-C $=2 \mathrm{~mm}$; D $=5 \mathrm{~mm}$. Photos: M. Jiménez.

cylindrical, subflexuous, 1.7-2.3 mm long between roots, covered by spiculate, imbricate, brown papery sheaths. Ramicauls terete, stout, $0.6-1.0 \mathrm{~mm}$ long, $0.4-0.6 \mathrm{~mm}$ in diameter, subtended by two tubular, imbricate, persistent, papery sheaths, $0.7-1.4 \mathrm{~mm}$ long. Leaves $3.3-4.0 \times$ 2.5-3.7 mm, thick, sessile, suborbicular or elliptic, dark green completely suffused with brown or only at the margin, verrucose and convex adaxially; suffused with magenta abaxially, verrucose and pitted, obtuse or subbilobed at the apex, margin involute, attached at its base to the ramicaul, younger leaves paler with brown-magenta veins. Inflorescence arising from the ramicaul, peduncle very short, $1.1 \mathrm{~mm}$ long, profusely covered with brownish purple spicules, floral bracts $0.5-1.3 \mathrm{~mm}$ long, infundibular, chartaceous; pedicel obconic, $1.0 \mathrm{~mm}$ long. Ovary obconic, greenish brown, glandular-spiculate, $1.2 \times$ $0.8 \mathrm{~mm}$. Sepals thick, widely concave from the basal half, glandular, shiny abaxially, with very sparse purple-red spicules externally, striped with cinnamon brown longitudinal lines. Dorsal sepal pale yellow, 5-veined, ovate, 
slightly recurved at the apex, subacute, $4.5-5.5 \times 2.6 \mathrm{~mm}$. Lateral sepals connate until near the apex to form an elliptic synsepal, pale yellow heavily suffused with caramel red or cinnamon brown, 8-veined, bifid at the apex, the apices apiculate, 5.2-6.1 × 2.6-3.0 mm. Petals translucent white with three wide yellow stripes, 3 -veined, triangular ovate, oblique, thick, shortly acuminate at the apex, slightly incurved at the base, apical internal zone pilose, $2.9-3.2 \times 0.7-0.8 \mathrm{~mm}$. Lip cinnamon brown or caramel red with pale yellow, 3-veined, verrucose-glandular adaxially, hinged to the column, oblong-subtrilobed, shortly attenuate and concave below the basal third, obtriangular from the apical third, margins denticulate, slightly raised at the apical third, two low keels near the middle, apex subotuse, $3.0 \times 1.3-1.4 \mathrm{~mm}$. Column yellow, semiterete, ventrally concave with revolute margins, apex shortly lobed, denticulate, $2.4 \times 0.7 \mathrm{~mm}$, column foot $1.1 \mathrm{~mm}$ long, concave. Anther ventral, white with a spot, $0.6 \mathrm{~mm}$ long, stigma ventral. Pollinia two, yellow.

Distribution. Known only from Ecuador.

Etymology. The specific name refers to the Cordillera del Cóndor, an important mountain range in southern Ecuador renowned for its high biological diversity.

Habitat and ecology. This species has been reported for the Cordillera del Cóndor of the Zamora Chinchipe Province in Ecuador. Phloeophila condorana occurs as an epiphyte on tree trunks and branches of Dacryodes peruviana (Fig. 3), Schefflera sp. and Chrysophyllum sanguinolentum in premontane forests of a sandstone plateau. The elevation ranges from 893 to $1210 \mathrm{~m}$ elevation. In nature, $P$. condorana blooms from April to September.

Notes. Phloeophila condorana is similar to the widely distributed $P$. nummularia. Even so, this new species is recognized by the much smaller pedicel $(1.0 \mathrm{~mm}$ long vs $2.6 \mathrm{~mm}$ ), the floral bract enclosing all the pedicel (vs enclosing nearly its half), the pedicel obconic (vs slender), the dorsal sepal ovate (vs oblong-obovate), the synsepal elliptic, 8-veined (vs oblong-elliptic, 10 -veined synsepal).

The colors of the flowers are also distinct. P. condorana has pale yellow dorsal sepal with cinnamon-brown stripes, and lateral sepals suffused with red (vs whitish gray dorsal sepal with reddish purple stripes and the lateral sepals pale yellow-brown), the petals have yellow stripes (vs brown stripes), the lip is suffused with red and yellow (vs brownish yellow with purple marks) and the column is yellow (vs yellowish brown with stripes).

The new species is also similar to Phloeophila ursula, a restricted endemic species from the Morona-Santiago province in Ecuador. This taxon differs by the larger plants and flowers, the densely pubescent ovary and sepals, the narrowly elliptic dorsal sepal, the obovate synsepal which is connate near the middle, the oblong petals, the ovatetrilobed lip and the column foot pubescent (Luer 2006).

Furthermore, all three species have been reported in southeastern Ecuador, Phloeophila condorana has been found growing in sympatry with $P$. nummularia at lower elevations from 890 to $1210 \mathrm{~m}$ in the Zamora-Chinchipe Province; while, according to Luer (2006), P. ursula grows in higher altitudes around $1600 \mathrm{~m}$ in the nearby province of Morona-Santiago. No intermediate specimens of $P$. condorana and $P$. nummularia have been found at the location where they grow together, suggesting that both species might have their individual pollinators.

Phloeophila condorana could be considered a restricted endemic species because it has not been found in other localities in Ecuador. Because the populations of the new species are not protected for any kind of conservation initiative and are mainly threatened by the abundant mining activity, the species may be considered as near threatened (NT) according to IUCN criteria (IUCN 2012). More
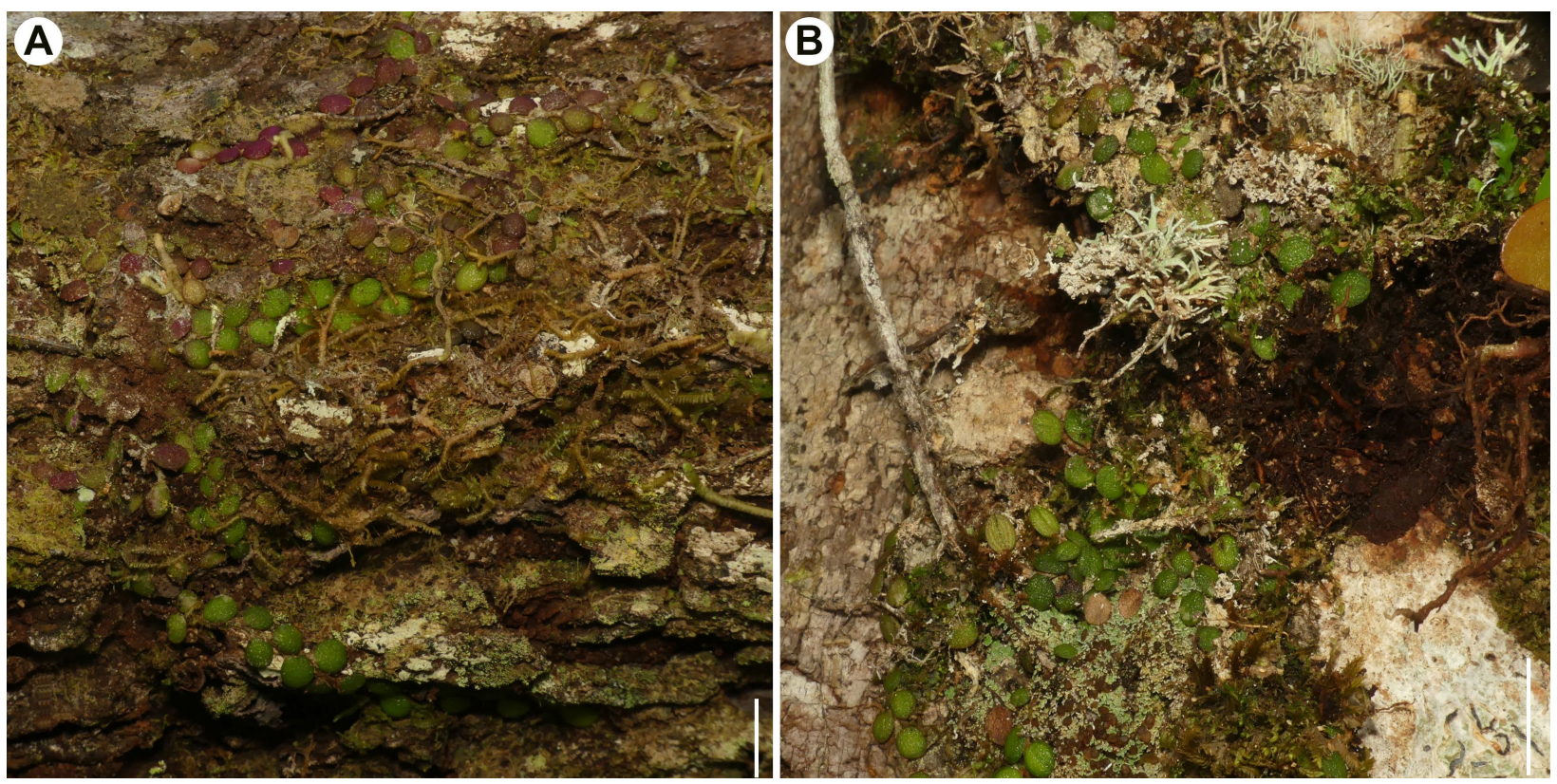

Figure 3. Phloeophila species in situ in the Cordillera del Cóndor. [A: Jiménez 991; B: Jiménez 998]. A - Phloeophila condorana; B - Phloeophila nummularia. Scales: A-B $=10 \mathrm{~mm}$. Photos: M. Jiménez. 
research will be conducted to get awareness of populations of $P$. condorana in the adjacent areas.

Phloeophila nummularia (Rchb.f.) Garay, Orquideología 9(2): 118. 1974.

(Figs 1-4, 6)

Basionym: Pleurothallis nummularia Rchb.f. Flora 48: 276. 1865.

Type: Caribbean, Cuba: Oriente, near Monte Verde, C. Wright 1513 (W - holotype!; AMES - isotype!).

三Specklinia nummularia (Rchb.f.) Luer. Monogr. Syst. Bot. Missouri Bot. Gard. 95: 262. 2004.

EPabstiella nummularia (Rchb.f.) Chiron. Richardiana 13: 131. 2013

$=$ Pleurothallis echinantha Barb. Rodr., Genera et Species Orchidearum Novarum 2: 22. 1881.

Lectotype: Brazil, Rio de Janeiro: Serra do Mar, near Rodeio, B. Rodrigues s.n. (lost). (Lectotype!, designated here). Barbosa Rodrigues' original drawing in the library of Jardim Botânico do Rio de Janeiro and reproduced in 'Iconographie des Orchidées du Brésil' by Sprunger et al. (1996, v.3, p. 235, t. 177A).

= Pleurothallis scalaris Griseb., Cat. P1. Cub. 259. 1866.

= Physosiphon echinanthus (Barb. Rodr.) Cogn., Flora Brasiliensis 3(4): 338. 1895.

= Phloeophila echinantha (Barb. Rodr.) Hoehne \& Schltr., Archivos de Botânica do São Paulo 1: 200. 1926.

= Phloeophila paulensis Hoehne \& Schltr., Archivos de Botânica do São Paulo 1: 201. 1926.

Type: Brazil, São Paulo: Estacão Biologica do Alto da Serra, Feb. 1919, F.C. Hoehne s.n. (B†-holotype).

= Pleurothallis paulensis (Hoehne \& Schltr.) Luer, Monogr. Syst. Bot. Missouri Bot. Gard. 20: 17. 1986.

Description. Plant epiphytic, repent, up to $9 \mathrm{~cm}$ long. Roots thick, flexuous, brownish, 0.4-0.6 mm diameter, produced every two-bract internodes of the rhizome. Rhizome cylindrical, 3.3-5.8 mm long between roots, covered by spiculate, imbricate, dark brown papery sheaths. Ramicaul terete, stout, 1.4-1.5 mm long, in diameter, subtended by tubular, imbricate, persistent, papery sheaths. Leaf 3.2-4.7 × 2.6-4.1 mm, thick, sessile, dark green and verrucose adaxially, whitish green suffused with purple and pitted abaxially, suborbicular, obtuse to subbilobed at the apex, attached at its base to the ramicaul, younger leaves paler with brown-purple veins. Inflorescence arising from the base of the ramicaul, peduncle $7.5 \mathrm{~mm}$ long, profusely covered with brown spiculate pubescence, floral bracts $1.2-1.9 \mathrm{~mm}$ long, infundibular, chartaceous; pedicel subflexuous, $2.6 \mathrm{~mm}$ long. Ovary obconic, pubescent-spiculate, $1.6 \mathrm{~mm}$ long. Sepals thick, deeply concave, shiny, with sparse purple-red spicules externally, striped with reddish purple longitudinal lines. Dorsal sepal whitish gray with a yellow apex, 5-veined, oblong-obovate, slightly recurved at the apex, acute, $6.6 \times 3.2 \mathrm{~mm}$. Lateral sepals connate until near the apex to form a pale yellow brown, 10-veined, oblong-elliptic synsepal, bifid at the apex, finely pubescent internally, $7.2 \times 3.4 \mathrm{~mm}$. Petals brownish-yellow with brown stripes, 3-veined, thick, oblong, acuminate, slightly incurved at the base, pubescent at the inner apex, $3.9 \times 0.6 \mathrm{~mm}$. Lip pale brownish-yellow with purple marks, 3-veined, oblong, shortly attenuate below the basal third, attenuate (obtriangular) from the apical third, slightly sinuate with margins slightly raised in the middle, microscopically pubescent-verrucose adaxially, apex subacute, papillose, $3.8 \times 1.4 \mathrm{~mm}$. Column pale yellow and brownish, faintly striped with brown, long, semiterete, concave with revolute margins ventrally, apex cucullate and the margin erose, $3.2 \times 0.8 \mathrm{~mm}$, column foot $1.0 \mathrm{~mm}$ long, anther white with a purple tip, apical, $0.7 \mathrm{~mm}$ long, rostellum protruding, stigma ventral. Pollinia two, $0.4 \mathrm{~mm}$ long.

Distribution. Cuba, Ecuador, Peru, Bolivia and Brazil.

Habitat and ecology. In Ecuador, this species has been reported for the Cordillera del Cóndor in Zamora Chinchipe Province. It was also reported by Luer (2006) from the specimen Hirtz 4807 collected near Tena. Phloeophila nummularia is found as an epiphyte on tree trunks of Dacryodes peruviana (Fig. 3) in premontane forests of a sandstone plateau. The altitudinal range goes from 800 to $1210 \mathrm{~m}$. In nature, $P$. nummularia blooms from February to September.

Specimens examined. BRAZIL. Minas Gerais: Serra do Caraça, Catas Altas, 15 Jan. 2005, R.C. Mota 3028 (BHCB-99694); Rio de Janeiro: Nova Friburgo, Serra de Macaé de Cima, vale do Rio das Flores, subida para os Pirineus, cumeada das C. velutina, 27 Feb. 2005, M. Moraes 607 (RB-00413840); Resende, Parque Nacional de Itatiaia, margem do Rio Campo Belo, perto do este 17, Parque Nacional de Itatiaia, 17 Oct. 1977, V.F. Ferreira 153 (RB-00352663); Silva Jardim, Rio Bonito de Macaé de Cima, Pico da Velutina ('Velutina's Ridge'), Entrada pela

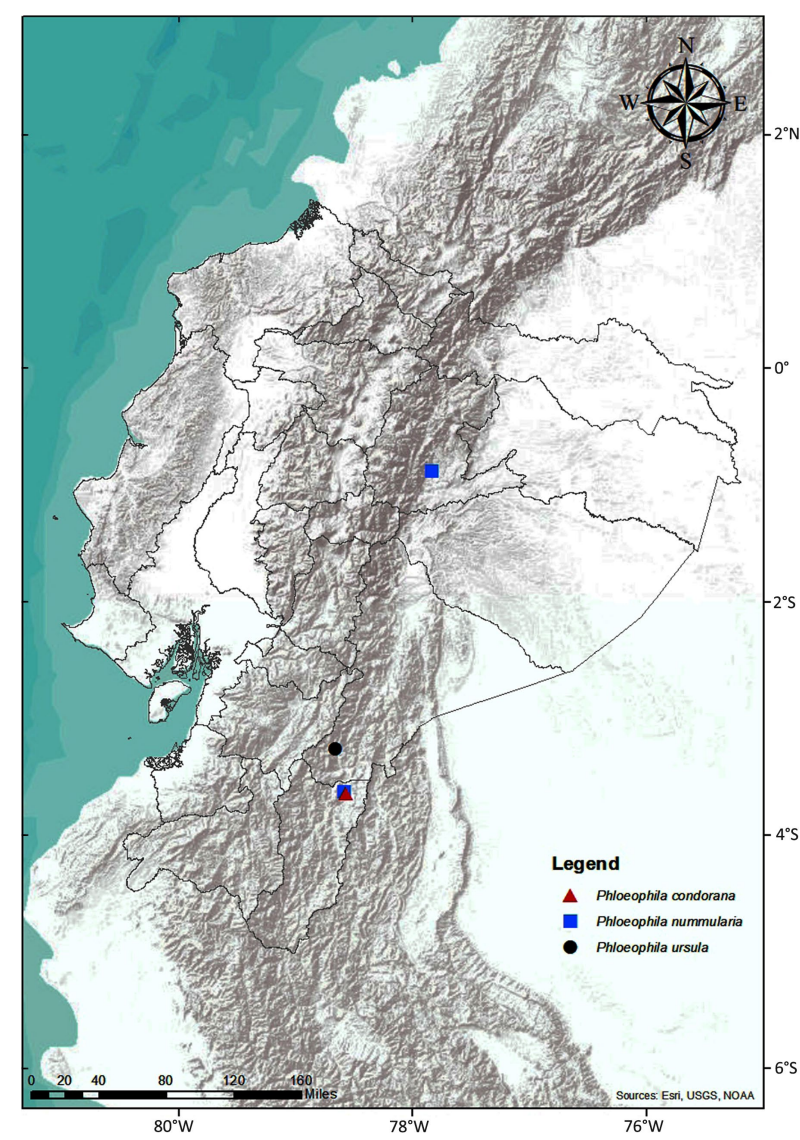

Figure 4. Distribution map of Phloeophila species in Ecuador using ArcGIS. 


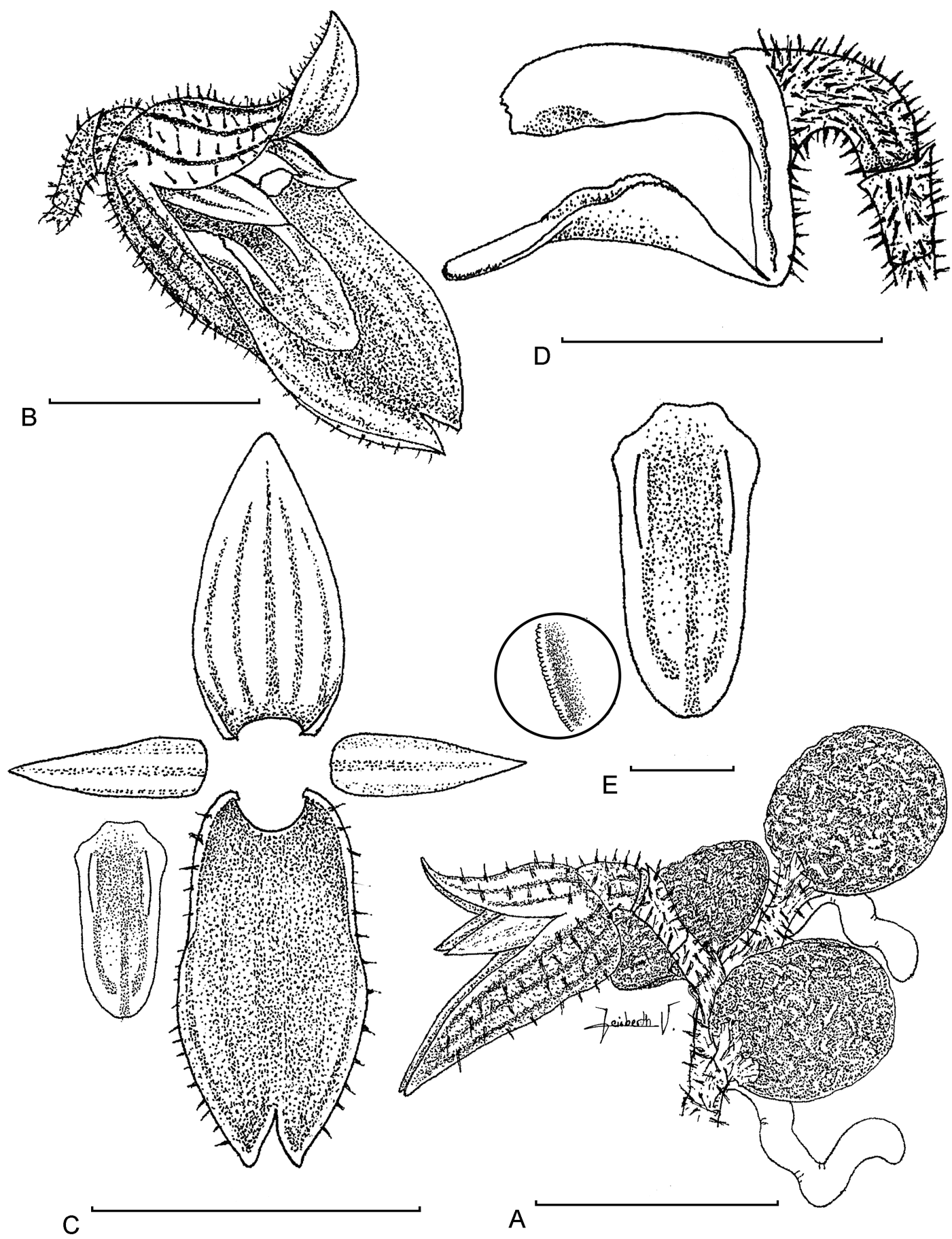

Figure 5. Phloeophila condorana [holotype]. A - Habit; B - Flower (lateral view); C - Dissected flower; D - Column, lip and ovary (side view); E - Lip (adaxial view) with detail of the margin. Scales: A, C = 5 mm; B, D = $3 \mathrm{~mm} ; \mathrm{E}=1 \mathrm{~mm}$. L. Vélez-Abarca del.

Reserva Biológica do Matão, APA Macaé de Cima, 08 Aug. 2016, C. Baez 700 (RB-01181445); São Paulo: Alto da Serra, matta da Estacão Biológica, 09 Jul. 1919, F.C. Hoehne 2998 (NY-512359); Alto da Serra, Estacão Biológica, Cultivada na estufa do Horto Oswaldo Cruz, Feb. 1919, F.C. Hoehne s.n. (SP-002313 - isotype!); Santo André, Alto da Serra, Estacão Biológica, Feb. 1919, F.C. Hoehne s.n. (USP-00072141 - isotype!); CARIBBEAN. Cuba: Monte verde, C. Wright 1573 (W-0027955 - holotype!); Monte Verde, 1859, C. Wright 1513 (GH-barcode-00074506 - isotype!); Oriente, near Monte Verde, C. Wright 1513 (BR-843 499 - isotype!); Prope Villam dictam, Jan-July 1859, C. Wright 1513 (K-000674239 - isotype!); Prope Villam dictam, Cuba Orientali, 1859, C. Wright 1513 (GOET009093); ECUADOR. Zamora Chinchipe: Cordillera del Cóndor flank, near El Pangui, 343'55"S, 78³3'41"W, 1210 m, 04 June 2020, M.M. Jiménez \& L. Vélez-Abarca 998 (HUTPL); PERU. Huánuco: Leoncio Prado, caserío Juan Santos, cerca de la zona de amortiguamiento del Parque Nacional Tingo María, marzo 2017, 1142 m, L. Ocupa et al. 201 (HUT).

Etymology. From the Latin nummularius, 'like little coins', referring to the shape of the leaves.

Notes. Phloeophila nummularia is considered as a widely distributed species from Cuba, Ecuador, Bolivia, to the south of Brazil (Luer 2006). This geographical distribution with three areas far away from each other is unusual. It is assumed $P$. nummularia will occur in Venezuela and 


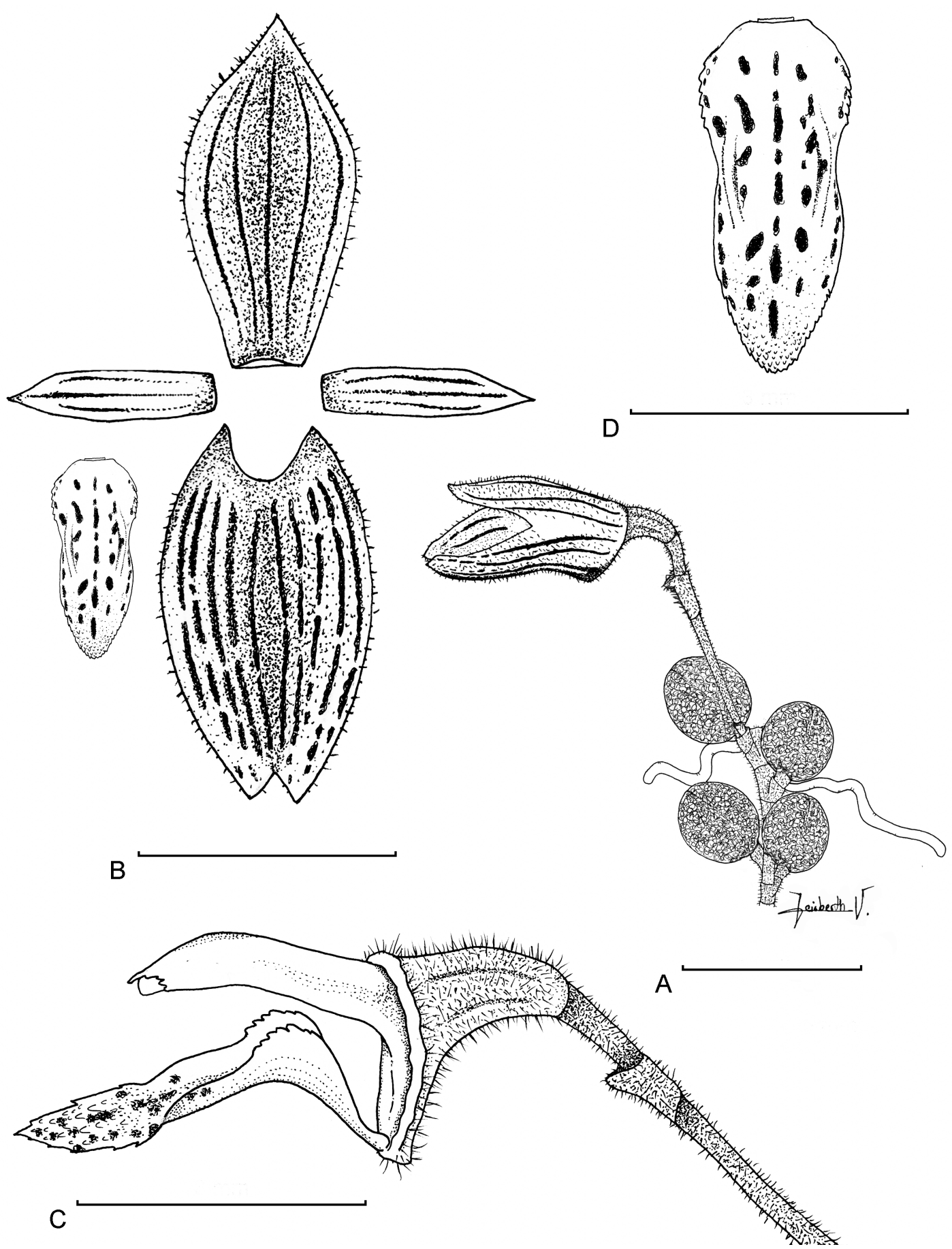

Figure 6. Phloeophila nummularia. [Jiménez 998]. A - Habit; B - Dissected flower; C - Column, lip, ovary and peduncle (side view); D - Lip (adaxial view) Scales: A-B $=5 \mathrm{~mm}$; $\mathrm{C}-\mathrm{D}=3 \mathrm{~mm}$. L. Vélez-Abarca del.

Colombia when a better exploration of the Amazon is carried out. This species is recorded for the first time here for Peru from a specimen collected in the department of Huánuco.

In Luer's (2006) monograph of Specklinia and vegetatively similar taxa, three line illustrations of morphotypes were included. One of them, collected by Alexander Hirtz in northeastern Ecuador, was mistakenly labelled as from Bolivia which in fact corresponds to a specimen characterized by having longer peduncle and pedicel. This morphotype is also illustrated here (Fig. 6). The same occurs with the specimen from Ecuador corresponding to a collection from Bolivia.
Following the concept of Luer (2006), Phloeophila nummularia is distinguished by its flower being larger than the leaf with fleshy and externally pubescent sepals, dorsal sepal shorter than the synsepal, connate near its half into a broad tube, acute and narrow petals, and the oblong lip with a pair of low calli and poorly defined lateral lobes on the lower third.

Phloeophila ursula (Luer \& Hirtz) Luer, Monogr. Syst. Bot. Missouri Bot. Gard. 105: 194, f. 150. 1996.

Basionym: Pleurothallis ursula Luer \& Hirtz, Lindleyana 11(3): 193-194, f. 66. 1996. 
Type: Ecuador, Morona-Santiago: Epiphytic in forest southeast of Sigsig near Chiguinda, 1600 m, 13 Jan 1989, C.A. Luer 13874 (MO - holotype!).

三Specklinia ursula (Luer \& Hirtz) Luer, Monogr. Syst. Bot. Missouri Bot. Gard. 2004.

Description. Plant epiphytic, repent, 10 or more cm long, roots slender. Rhizome cylindrical, $1 \mathrm{~mm}$ long between ramicauls, covered by thin, imbricate, tubular sheaths. Ramicaul terete, stout, $1.0 \mathrm{~mm}$ long, subtended by short, tubular, spiculate sheaths. Leaf 6.0-7.5 × 5.0-6.0 mm, thick, sessile, verrucose adaxially, broadly elliptic to suborbicular, broadly cuneate at its base. Inflorescence arising from the ramicaul, peduncle $2 \mathrm{~mm}$ long, covered by spiculate sheaths, floral bracts, $2.0 \mathrm{~mm}$ long, spiculate; pedicel $1.5 \mathrm{~mm}$ long. Ovary densely pubescent, $1.5 \mathrm{~mm}$ long. Sepals fleshy, purplish brown, dotted with dark purple, densely pubescent externally. Dorsal sepal 3 -veined, $7.0 \times 2.0 \mathrm{~mm}$, narrowly elliptic, concave, subacute, recurved at the apex, connate to the lateral sepals for $2 \mathrm{~mm}$. Lateral sepals $10.0 \times 4.0 \mathrm{~mm}$, connate to near the middle, obovate, oblique, acute, 3-veined, bifid at the apex. Petals 3-veined, yellow, glabrous, oblong, $3.5 \times$ $1.0 \mathrm{~mm}$, subacute, minutely verrucose at the apex. Lip $4.5 \times 1.5 \mathrm{~mm}$, brown, ovate-trilobed, ovate up the middle, denticulate, verrucose, the lateral lobes erect, rounded below the middle, with a pair of low, verrucose calli extending from the bases of the lobes onto a disc above the middle, the base truncate, articulated to the column foot. Column terete, $3 \mathrm{~mm}$ long, apex denticulate, column foot $2 \mathrm{~mm}$ long; anther rostellum and stigma ventral.

Distribution. Known only from Ecuador.

Habitat and ecology. This species has been only reported for the Chigüinda surrounding area in the Morona-Santiago province, Ecuador. Phloeophila ursula grows apressed upon the mossy bark of the trees (Luer 1996).

Etymology. From the Latin ursula, 'a bear cub', in allusion to the pubescent vegetative and floral parts.

Notes. In this study, no living material of Phloeophila ursula was collected. This species is similar to P. nummularia, but is distinguished by the proportionally larger flowers, the dorsal sepal considerably smaller than the lateral sepals, the petals minutely verrucose at the apex and the apical half of the lip, denticulate and verrucose (Luer 1996).

\section{Acknowledgements}

We thank Alexander Damián and Dave Skinner for helping with language corrections and other observations in this manuscript. We also thank Ángel Benitez (UTPL) for promoting the preparation of this manuscript and for his valuable suggestions, comments and observations to improve it. We thank Luis Ocupa Horna and Marco Monteros for his help with this investigation. We acknowledge Universidad de Las Américas (UDLA) for funding research on orchids in Ecuador and the Ministerio del Ambiente (MAE) for granting the Research Permit No. 008-2016-IC-FLO-DNB/MA. The authors also acknowledge the anonymous reviewers and Editor for helping with comments and corrections of this manuscript. This research is part of the master's dissertation of the first author, conducted at the Universidad Técnica Particular de Loja.

\section{References}

Chiron, G. R., Karremans, A. P. \& Van den Berg, C. 2016. Nomenclatural notes in the Pleurothallidinae (Orchidaceae): Phloeophila. Phytotaxa 270: 056-062. https://doi.org/10.11646/phytotaxa.270.1.6

Chumová, Z., Trávníček, P., Ponert, J., Záveská, E., Mandákova, T., Hloušková, P., Certner, M. \& Schmidt, P.-A. 2018. Pleurothallidinae - a hyper-diverse subtribe with hyper-diverse genomes. Poster at the European Orchid Show \& Conferences, Paris, March 23-25th, 2018.

Dodson, C. H. 2003. Native Ecuadorian Orchids. Volume IV: OncidiumRestrepiopsis. Dodson Trust. Sarasota, Florida, USA.

Garay, L. A. 1974. Acostaea Schltr. y los géneros del complejo Pleurothallis. Orquideología 9: 103-125.

IUCN. (2012). IUCN Red List Categories and Criteria: Version 3.1. IUCN Species Survival Commission. Gland, Switzerland, and Cambridge, United Kingdom, 30 pp.

Karremans, A. P. 2016. Genera Pleurothallidinarum: overview of Pleurothallidinae. Lankesteriana 16: 219-241. https://doi.org/10.15517/ lank.v16i2.26008

Karremans, A. P. \& Vieira-Uribe, S. 2020. Pleurothallids Neotropical Jewels - Volume 1. Imprenta Mariscal, Quito, Ecuador.

Lind, R. 2012. Open Source Software in Life Science Research: Practical Solutions in the Pharmaceutical Industry and Beyond. Abington, Cambridge UK: Woodhead Publishing Ltd.

López, G., Solano, R. \& Pérez-Farrera, M. Á. 2007. Primer registro de Phloeophila (Orchidaceae: Pleurothallidinae) para la flora de México. Acta Botánica Mexicana 78: 77-83. https://doi.org/10.21829/ abm78.2007.1031

Luer, C. A. 1986. Icones Pleurothallidinarum III. Systematics of Pleurothallis. Monographs in Systematic Botany from the Missouri Botanical Garden 20: 17.

Luer, C. A. 1996. New species of Pleurothallis (Orchidaceae) from Ecuador. Lindleyana 11: 72-73.

Luer, C. A. 2006. Icones Pleurothallidinarum XXVIII. A reconsideration of Masdevallia. Systematics of Specklinia and vegetative similar taxa (Orchidaceae). Monographs in Systematic Botany from the Missouri Botanical Garden 105: 191.

Ponert, J., Chumová, Z., Záveská, E., Mandákova, T., Hloušková, P., Certner, M., Schmidt, P.-A. \& Trávníček, P. 2019. Understanding of complex diversity in the Pleurothallidinae as the way to effective conservation. Poster presented at the 7th International Orchid Conservation Congress, Kew, London, May 28th-June 1st, 2019.

Pridgeon, A. M. \& Chase, M. W. 2001. A phylogenetic reclassification of Pleurothallidinae (Orchidaceae). Lindleyana 16: 235-271.

Pridgeon, A. M., Solano Gómez, R. \& Chase, M. W. 2001. Phylogenetic relationships in Pleurothallidinae (Orchidaceae): combined evidence from nuclear and plastid DNA sequences. American Journal of Botany 88: 2286-2308. https://doi.org/10.2307/3558390 